\title{
THE SPIDER GENERA STEATODA AND ENOPLOGNATHA IN AMERICA* (ARANEAE, THERIDIIDAE)
}

\author{
By Herbert W. Levi \\ Museum of Comparative Zoology, Harvard University
}

The previous revisions (Levi, 1957a, 1957b) of the two genera Enoplognatha and Steatoda considered only the North American species. Since the revisions were published, large South American collections have become available and the types of South American species could be consulted.

The majority of species of both genera are found in the north temperate zone and are fairly well known. The additional species described here from the neotropical area are sometimes intermediate between the two genera. Enoplognatha peruviana may lack the tooth on the posterior margin of the chelicerae as in Steatoda species. The males of several Steatoda (e.g. S. andina) have the chelicerae enlarged as is characteristic of Enoplognatha. South American Enoplognatha species are found only in southern Peru and northern Chile (Map I). The genus has no representatives in Central America or the West Indies. Steatoda species are found in all parts of South America, with several endemic species and several that are widespread ( $S$. ancorata, S. grossa, S. moesta). Unlike Anelosimus species (Levi, in press) Steatoda species cross the desert or mountain barrier into Chile (Map 2).

The types of species could be examined through the hospitality and cooperation of Dr. G. Owen Evans and Mr. D. Clark of the British Museum (Natural History) ; Prof. G. C. Varley of the Hope Department of Entomology, Oxford; Dr. L. Brundin of the Natural History Museum, Stockholm; Prof. M. Birabén of the Museo de la Plata; Prof. M. Vachon of the Muséum National d'Histoire Naturelle, Paris; Mr. J. Prószyński of the Polish Academy of Sciences, Warsaw; Dr. L. Forcart of the Naturhistorisches Museum, Basel and Dr. M. Beier of the Naturhistorisches Museum, Vienna. I would like to thank the following for the loan of specimens for study: Prof. M. Vachon, Muséum National d'Histoire Naturelle (MNHN); Mr. J. Kekenbosch of the Institut Royal des Sciences Naturelles, Brussels (ISNB) ; Dr. W. J. Gertsch of the American Museum of Natural History (AMNH); Dr. O. Kraus of the Senckenberg Museum,

\footnotetext{
*Manuscript received by the editor November 20, 1961.
} 
Frankfurt (SMF) ; Dr. E. S. Ross of the California Academy of Sciences (CAS) ; Dr. H. Exline (Mrs. D. Frizzell) for specimens from northern Peru and Ecuador collected by herself and others; Dr. R. X. Schick of California; Miss H. Zapfe (Mrs. G. Mann) of Santiago de Chile; Dr. J. Abalos of Santiago del Estero and Prof. H. Stahnke of Arizona. A trip to European museums to examine types was made possible by a National Science Foundation Grant (G-43I7) and the research was supported by a grant from the National Institutes of Health (E-1944).

\section{Enoplognatha Pavesi}

Enoplognatha Pavesi, 1880, Ann. Mus. Civ. Stor. Nat. Genova, vol. 15, p. 325. Type species by original designation and monotypy Theridion mandibulare Lucas.

Diagnosis. Medium sized to large theridiid spiders. Enoplognatha, like Steatoda, has a large colulus and a subspherical abdomen. Females have a tooth on the posterior margin of the chelicerae. Males usually have enlarged chelicerae, with enlarged teeth and have the paracymbium on the margin of the cymbium (Levi and Levi, 1962).

Species misplaced. Enoplognatha dubia Chamberlin, 1916 $=$ Anelosimus studiosus (Hentz, I850). Enoplognatha triangulifera Simon, $1902=$ Anelosimus recurvatus ('Tullgren, I901).

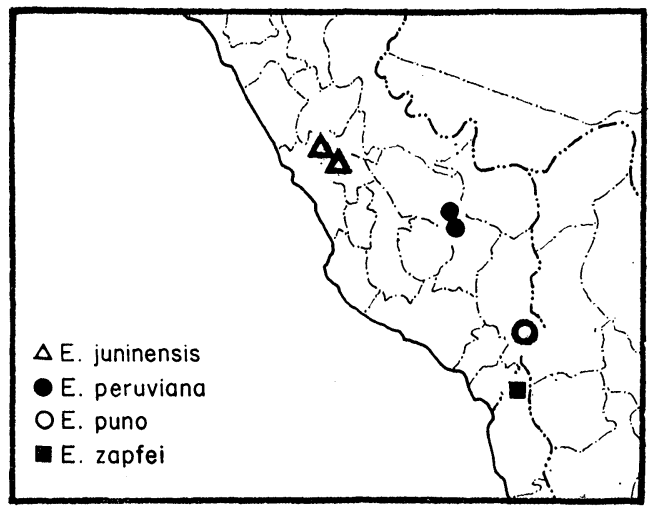

Map 1. Distribution of South American Enoplognatha species.

Key to American Species of Enoplognatha

Ia. Species found in South America

Ib. Species found in north of Mexico 
2a. Epigynum with a large central depression (Figs. I2, I3, I5) 3

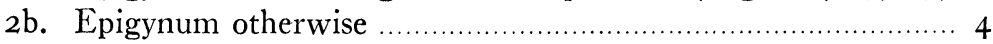

3a. Epigynum with central depression surrounded by a lip (Figs. I 2, I3) ; ducts coiled (Fig. I I ) ; Peru

E. juninensis (Keyserling)

3b. Epigynum with central depression lacking a lip posterior (Fig. I 5) ; ducts with a sclerotized loop (Fig. I4); Chile

E. zapfei n. sp.

4a. Fused ducts extending anterior and surrounding seminal receptacles (Fig. 9)

E. puno n. sp.

4b. Fused ducts not extending anterior of seminal receptacles (Fig. 7)

E. peruviana Chamberlin

5a. Yellow-white coloration with black or red lines on carapace and abdomen (I957a, fig. 4); introduced in northeastern and Pacific coast states ............................... E. ovata (Clerck)

5b. Gray, brown or black coloration ...................................... 6

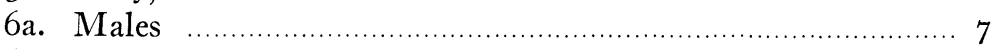

6b. Females ............................................................ I 4

7a. Lacking paracymbium on cymbial margin (Fig. 4); Arizona, southeastern California ........................... E. maricopa n. sp.

7 b. With paracymbium on cymbial margin .......................... 8

8a. Conductor with a stalked distal apophysis (I957a, fig. I3-16) 9

8b. Conductor otherwise ............................................... Io

9a. Conductor apophysis widened distally and truncate (1957a, figs. 15, I6) ; California ................. E. selma Chamberlin and Ivie

9b. Conductor apophysis pointed distally (I957a, figs. I3, I 4) ; introduced in Oregon ........................... E. thoracica (Hahn)

IOa. Chelicerae with two subequal teeth on posterior margin (1957a, figs. 24, 25)

Iob. Chelicerae with one large mesal tooth (I957a, figs. 46-48) I 2

I Ia. Abdomen with a spotted dorsal pattern ( 1957a, fig. 33) ; median apophysis in ventral view only in distal half of alveolus (1957a, fig. 26); widespread throughout United States and southern Canada, Mexico ............................. E. marmorata (Hentz)

I Ib. Abdomen with a foliate dorsal pattern ( I957a, fig. 37); median apophysis in ventral view extending into proximal half of alveolus (1957a, fig. 28) ; east of Rocky Mountains to Newfoundland ...................................... E. tecta (Keyserling)

12a. Ectal portion of conductor with long axis almost parallel to axis of cymbium (1957a, figs. 42-45); western states, rare in east

$E$. joshua Chamberlin and Ivie 
I2b. Long axis of ectal portion of conductor at almost right angles to axis of cymbium ( 1957 a, figs. 38,40 )

13a. Embolus more proximal, conductor with a longer ectal portion (figs. 38, 39) ; South Dakota to Utah at lower elevations

E. wyuta Chamberlin and Ivie

I3b. Embolus more distal, conductor with a shorter ectal portion (I957a, figs. 4O, 4I ) ; Alaska to Greenland, in Rocky Mountains above timberline and in spruce-fir forest, Minnesota, Pennsylvania. New England ........... E. intrepida (Sørensen)

I4a. Epigynum with a light posterior transverse bridge (1957a, fig. 55 ) ; western states, rare in east .. E. joshua Chamberlin and Ivie

I 4b. Epigynum otherwise I 5

I5a. Epigynum with an oval depression having dark marks of openings on the anterior of the depression (1957a, fig. 20); California E. selma Chamberlin and Ivie

I 5b. Epigynum otherwise ............................................... I6

I6a. Epigynum with a transverse swelling, with a seam on the anterior and openings on each end of seam ( 1957a, fig. I8); introduced in Oregon E. thoracica (Hahn)

I6b. Epigynum otherwise I 7

I 7a. Epigynum with distinct dark marks indicating openings ....... I9

I 7 b. Epigynum with diffuse dark marks .............................. I 8

I 8a. Swelling of epigynum divided by a transverse groove (i957a, figs. 31, 32), spotted dorsal abdominal pattern ( I957a, fig. 33) ; widespread throughout United States and southern Canada, Mexico ........................................ E. marmorata (Hentz)

I8b. Epigynum swelling undivided with only a slight depression posterior ( I 957a, figs. 35, 36), foliate dorsal pattern of abdomen ( I957a, fig. 37) ; east of Rocky Mountains to Newfoundland E. tecta (Keyserling)

19a. Dark mark of epigynum anterior to a light swelling (Fig. 2); Arizona, southeastern California E. maricopa n. sp.

I9b. Dark mark anterior to a transverse ridge 20

20a. Posterior edge of dark mark of epigynum straight (1957a, fig. $50)$; South Dakota to Utah at lower elevations

E. wyuta Chamberlin and Ivie

2ob. Dark mark dumb-bell shaped (1957a, fig. 52); Alaska to Greenland, in Rocky Mountains above timberline and in sprucefir forest, Minnesota, Pennsylvania, New England 
Enoplognatha selma Chamberlin and Ivie

Additional record. California. Los Angeles Co.: Big Tujunga Canyon, San Gabriel Mts., 3 June 1955 (R. X. Schick).

\section{Enoplognatha marmorata (Hentz) and Enoplognatha tecta (Keyserling)}

Although these are common species in the eastern United States, we still have few observations on their habits. Mature E. tecta have been collected on a garage door in Cambridge, Massachusetts and numerous specimens were collected rolled up in leaves in herbaceous vegetation along forest edge about $40 \mathrm{~cm}$ above ground in southern Minnesota, in an area where E. marmorata was collected under boards in gardens.

Additional records of E. marmorata. Canada. British Columbia: Muskeg near Little Prairie (D. Rounds). Mexico. Hidalgo: Guerrero Mill (W. M. Mann).

\section{Enoplognatha maricopa new species}

Figures I-5

Type. Male from Phoenix, Maricopa County, Arizona, I I March 1960 (H. L. Stahnke) in the Museum of Comparative Zoology.

Description. Male carapace, sternum, legs red-brown. Abdomen mottled purplish. Sclerotized portion of epigastric area and plate above pedicel on abdomen red-brown. Carapace with a circular thoracic depression. Anterior median eyes smallest, anterior laterals largest. Anterior median eyes a little less than a diameter apart, their radius from laterals. Posterior median eyes a little less than a diameter apart, one diameter from laterals. Chelicerae heavy but not elongated, with one large anterior tooth (Fig. 5). Total length $3.4 \mathrm{~mm}$. Carapace $1.8 \mathrm{~mm}$ long, I. $3 \mathrm{~mm}$ wide. First patella and tibia $\mathrm{I} .4 \mathrm{~mm}$; second $1.3 \mathrm{~mm}$; third $1.0 \mathrm{~mm}$. Fourth femur I. $3 \mathrm{~mm}$; patella and tibia $1.6 \mathrm{~mm}$; metatarsus $1.2 \mathrm{~mm}$; tarsus $0.5 \mathrm{~mm}$.

Female carapace, sternum and legs mottled brown or yellowish. Abdomen with a black pattern on dorsum as in Enoplognatha wyuta Chamberlin and Ivie (1957a, fig. 53). Anterior median eyes smaller than others. Anterior medians one and one-half diameters apart, one diameter from laterals. Posterior median eyes one diameter apart, a little more than one diameter from laterals. Chelicera with one anterior tooth and three denticles between tooth and base of fang. 
Posterior margin of chelicera with one small tooth (missing on one side of one specimen). Total length one female $2.9 \mathrm{~mm}$, another 3.8 $\mathrm{mm}$. Carapace of the latter $1.5 \mathrm{~mm}$ long, $1.2 \mathrm{~mm}$ wide. First femur I.6 $\mathrm{mm}$; patella and tibia $1.8 \mathrm{~mm}$; metatarsus $1.0 \mathrm{~mm}$; tarsus 0.8 $\mathrm{mm}$. Second patella and tibia $\mathrm{I} .5 \mathrm{~mm}$; third I.I $\mathrm{mm}$; fourth $1.8 \mathrm{~mm}$.

Comments. It is not certain that the male and female described here belong together. However, since large collections of spiders are available from southern and southeastern Arizona and no specimens of Enoplognatha have been found, I assume that the distribution of Enoplognatha maricopa is north from the type locality, where the females were found, a poorly collected area.

Diagnosis. The palpus differs from other North American species in that there is no paracymbium on the margin of the cymbium (Fig. 4). However, the transparent edge of the cymbium is difficult to see. On the mesal side of the bulb is a sclerite, probably part of the conductor, which has two projections, one toward the venter and one toward the distal end of the palpus (Fig. 3). The female differs from Enoplognatha intrepida (Sørensen) in that it has two dark openings connected by a black groove; posterior to the groove is a swelling having a lighter center (Fig. 2).

Records. California. Placer Co., near Emigrant Gap, 8 July 1956, 2 오 (V. Roth, W. J. Gertsch, AMNH) ; Tahoe City, 8 July 1956, of (W. J. Gertsch, V. Roth, AMNH).

\section{Enoplognatha peruviana Chamberlin Figures 6-8}

Enoplognatha peruviana Chamberlin, 1916, Bull. Mus. Comp. Zool., 60:232, pl. 16, figs. 8-11, + . Female type from Urubamba, $3100 \mathrm{~m}$ alt., [Cuzco], Peru, in the Museum of Comparative Zoology, examined.

Description. Carapace, sternum, legs red-brown. Abdomen black with a dorsal pattern as in Enoplognatha tecta (Keyserling), (1957a, fig. 37). Anterior median eyes two-thirds diameter apart, one diameter from laterals. Posterior median eyes two-thirds diameter apart, one and one-half diameters from laterals. Anterior median eyes slightly smaller than others. Cheliccra with three large teeth on anterior margin, the first and third larger than the middle one; none on posterior margin of the type. However, another specimen seems to have the posterior tooth. Colulus relatively small with two setae. Total length of female type $6.5 \mathrm{~mm}$. Carapace $3.6 \mathrm{~mm}$ long, $2.4 \mathrm{~mm}$ wide. First femur, $2.7 \mathrm{~mm}$; patella and tibia, $3.4 \mathrm{~mm}$; 
metatarsus, $2.0 \mathrm{~mm}$; tarsus, I. I $\mathrm{mm}$. Second patella and tibia, $3.0 \mathrm{~mm}$; third, $2.3 \mathrm{~mm}$; fourth, $3.2 \mathrm{~mm}$.

The male illustrated (Fig. 6) may belong to this species; this is uncertain, as is the locality where it has been found.

Records. Peru. "Pampa Machei, 4400 m," Feb. i947, ơ (Brecht, AMNH). Cuzco: Cuzco, 3500 m, July i947, 우 (W. Weyrauch, AMNH).

\section{Enoplognatha puno new species}

Figures 9, ro

Type. Female from $32 \mathrm{~km}$ north of Desaguadero, Puno, Peru, 27 Feb. I95 I (E. I. Schlinger, E. S. Ross), in the California Academy of Sciences. The specific name is a noun in apposition, after the type locality.

Description. Carapace, sternum, legs dark brown. Abdomen brownish black with an indistinct dorsal pattern as in E. peruviana. Venter with some white pigment on each side. Anterior median eyes much smaller (two-thirds their diameter) than oval posterior eyes. Anterior median eyes two-thirds diameter apart, more than their diameter from laterals. Posterior median eyes less than their shorter diameter apart, two and one-half times their shorter diameter from laterals. Chelicerae with three large anterior teeth and a minute denticle on posterior margin. Total length 6.I mm. Carapace 2.6 $\mathrm{mm}$ long, $2.0 \mathrm{~mm}$ wide. First femur $2.3 \mathrm{~mm}$; patella and tibia 2.9 $\mathrm{mm}$; metatarsus I.7 mm; tarsus I.O mm. Second patella and tibia 2.5 $\mathrm{mm}$; third $2.1 \mathrm{~mm}$; fourth $3.0 \mathrm{~mm}$.

Diagnosis. Only the epigynum (Fig. IO) and ducts of the internal genitalia (Fig. 9) separate this species from E. peruviana; the pattern and the structure are very similar. It is possible that this species belongs to a geographical race of $E$. peruviana.

\section{Enoplognatha juninensis (Keyserling) \\ Figures I I-I 3}

Lithyphantes juninensis Keyserling, 1884, Die Spinnen Amerikas, Theridiidae $2(1): 143$, pl. 6, fig. 90, + . Female lectotype here designated from Maraynioc, Junín, Peru in the Polish Academy of Sciences, Warsaw, examined.

Enoplognatha juninensis, Simon, 1894, Histoire Naturelle des Araignées, 1: 578.

The specimen examined from Pasco, Peru has the abdomen dark gray with a light area on each side on dorsum; the venter is also dark 
gray with a light area on each side between cpigynum and spinnerets. The chelicerae have three large teeth on the promargin, a minute
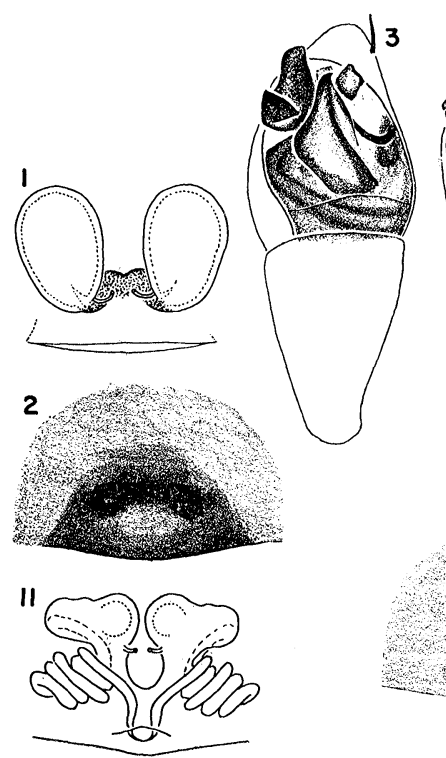

12

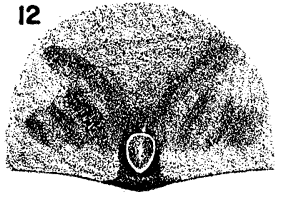

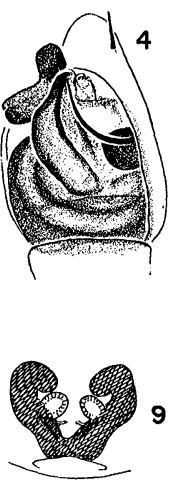
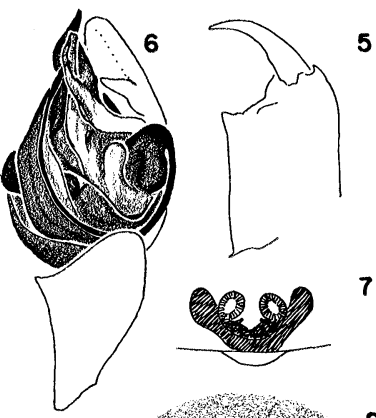

10
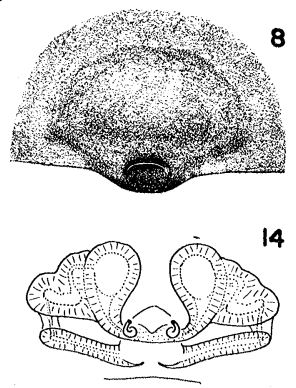

13

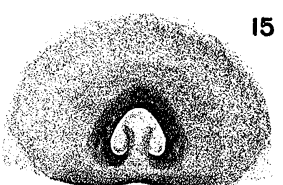

Figs. 1-5. Enoplognatha maricopa new species. 1. Female genitalia, dorsal view. 2. Epigynum. 3, 4. Left palus. 3. Ventral view. 4. Ectal view. 5. Left male chelicera, posterior view.

Figs. 6-8. E. peruviana Chamberlin. 6. Palpus (doubtful determination). 7. Female genitalia, dorsal view. 8. Epigynum.

Figs. 9-10. E. puno new species. 9. Female genitalia, dorsal view. 10. Epigynum.

Figs. 11-13. E. juninensis (Keyserling). 11. Female genitalia, dorsal view. 12, 13. Epigynum.

Figs. 14-15. E. zapfei new species. 14. Female genitalia, dorsal view. 15. Epigynum.

tooth on the posterior margin. The colulus is large, almost transparent white, with two setae from the base.

Records. Peru. Pasco: near Huayllay, 4400 m, io Aug. I953, 
ㅇ (H. W. Koepcke, SMF). Junin. Maraynioc, ㅇ paratype with o paratype $(\mathrm{BMNH})$.

\title{
Enoplognatha zapfei new species
}

\author{
Figures 14, I 5
}

Type. Female from Putre, Province Tarapacá, Chile, Feb. 1948 (Avilés), in the Museum of Comparative Zoology. The species is named after Miss H. Zapfe of Santiago de Chile.

Description. Carapace dark yellow, darker around anterior median eyes. Chelicerae red-brown. Sternum, legs dark yellow. Abdomen gray with darker gray mottled pattern on dorsum and a pair of longitudinal lighter bands between genitalic area and spinnerets. Anterior median eyes slightly smaller than others. Anterior lateral eyes on slight tubercles. Anterior median eyes slightly less than one diameter apart, a little more than one diameter from laterals. Posterior median eyes three-quarters diameter apart, two diameters from laterals. Chelicerae with three teeth on anterior margin, a blunt indistinct tooth posterior. Total length $9.2 \mathrm{~mm}$. Carapace $4.5 \mathrm{~mm}$ long, $3.4 \mathrm{~mm}$ wide. First femur, $4.1 \mathrm{~mm}$; patella and tibia, $5.0 \mathrm{~mm}$; metatarsus, $3.4 \mathrm{~mm}$; tarsus, $1.6 \mathrm{~mm}$. Second patella and tibia, $4.3 \mathrm{~mm}$; third, $3.7 \mathrm{~mm}$; fourth, $5.1 \mathrm{~mm}$.

Diagnosis. This large species of Enoplognatha can be separated from $E$. juninensis by the lack of posterior lip in the opening of the depression of the epigynum (Fig. I5) and by lack of the internal coiled duct. The ducts of $E$. zapfei are heavily sclerotized adjacent to the seminal receptacles (Fig. I4).

\section{Steatoda Sundevall}

Steatoda Sundevall, 1833, Conspectus Arachnidum, p. 16. Type species designated by Thorell, 1869, On European Spiders, p. 93. S. castanea (Clerck, 1757).

Diagnosis. Medium-sized to large theridiid spiders, usually dark in coloration. Colulus very large. Chelicerae armed with a tooth or several teeth on anterior margin. But unlike Enoplognatha, it has no teeth on the posterior margin of female chelicerae. Abdomen subspherical. Males often with enlarged chelicerae and a sclerotized ring around pedicel on anterior end of abdomen. The abdomen of most species has a white line around anterior of dorsum, in addition to other lines or spots (Levi and Levi, I962).

Note. The common species of North America were described in 
a previous paper (Levi $1957 \mathrm{~b}$ ). In this paper the ventral view of the genitalia (cleared epigynum) was illustrated, not the dorsal as in most of my papers on theridiid spiders. Gertsch (1960) has taken issue with my treatment of species of the "fulva" group in the previous paper and has named several new species. However, insufficient ecological and life history data are available for the possible species involved to permit making a final decision now (Levi, 1960). Thus the only species recognized are those of my previous revision.

Steatoda brasiliana Keyserling, I884, Die Spinnen Amerikas Theridiidae, 2(I) : I 15, pl. 5, fig. 75, $0^{7}$. Male type from Rio de Janeiro, Brazil in the Naturhistorisches Museum, Vienna, examined is a male Steatoda bipunctata (Linn.) from Europe (NEW SYNONYMY). The female described by Keyserling in 1886 as $S$. brasiliana is probably a specimen of $S$. moesta (Keyserling).

Species misplaced: Lithyphantes juninensis Keyserling $=$ Enoplognatha juninensis (Keyserling).

Steatoda rubra Keyserling, I886, Die Spinnen Amerikas, Theridiidae, 2(2) : 239, pl. 20, fig. 294, ㅇ. Female type from Blumenau, Brazil $=$ Theridion rubra (Keyserling).

\section{Key to American Species of Steatoda}

Ia. Epigynum with a prominent, wide, transverse bridge; areas anterior and posterior to bridge shallow depressions (1957b, figs. 43, 44, 46, 47, 49, 50) ; palpus with thread-like embolus on venter, evenly curved, with a membrane inside embolus loop from base supporting a portion of embolus (1957b, figs. 32-4I); North America

S. fulva group

Ib. Epigynum without transverse bridge or if with bridge, then areas anterior and posterior to it not depressed; embolus otherwise or if similar South American

2a. Seminal receptacles thickened, sclerotized, coiled ends of ducts ( 1957b, figs. 88, 92, 98, 116) ; epigynum having a U-shaped depression (1957b, figs. 105, I07-I09) or a shallow circular depression containing anterior a deeper depression on each side of a septum (rarely absent) (1957b, figs. 93, 97, 99-103) or epigynum as in $1957 \mathrm{~b}$, fig. 89 ; palpus with a prominent $\mathrm{U}$ shaped radix on mesal side (1957b, figs. I I9, I24, I29, I34, I 45, I 55); North America S. bipunctata group

Map 2. Distribution of South American Steatoda species. 


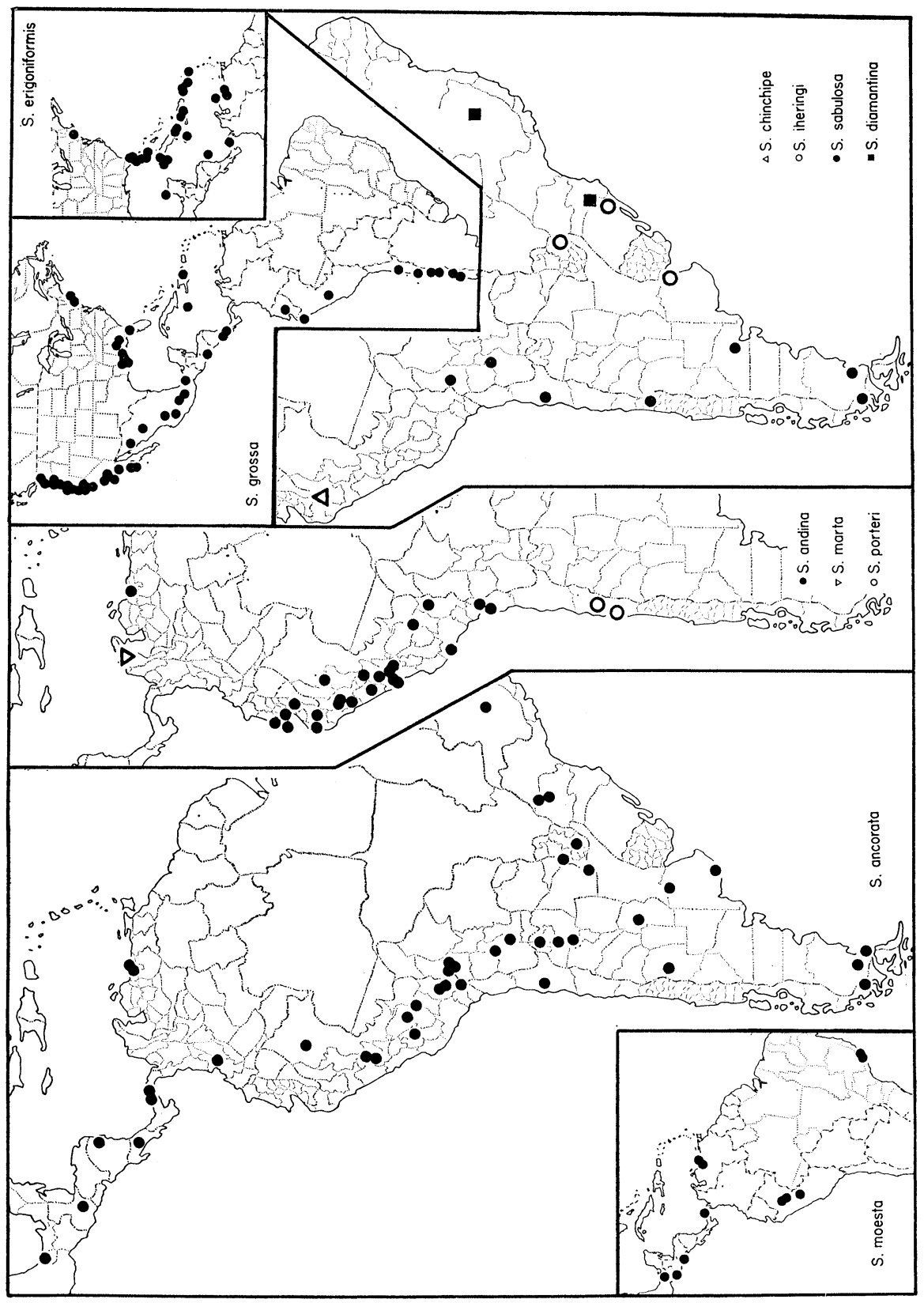


2b. Seminal receptacles oval or spherical; epigynum and palpus otherwise or if similar, not North American ......................... 3

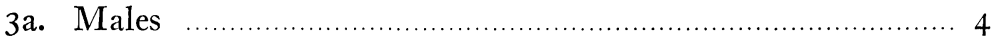

3b. Females ................................................................... I7

4a. Palpus with a large mesal projecting radix (1957b, figs. 59, 68)

4b. Palpus otherwise ............................................................... 6

5a. Embolus short, radix longer than half length of bulb (1957b, fig. 59); southern Canada to central Mexico

S. albomaculata (DeGeer)

5b. Embolus long, radix less than half length of bulb (1957b, fig. $68)$; southern Canada to central Mexico, common in northeastern states

S. americana (Emerton)

6a. Palpal tibia one and one-half times length of cymbium (I957b, fig. 76) ; probably introduced and widespread in United States, rare in South America ................ S. triangulosa (Walckenaer)

6b. Palpal tibia as long as or shorter than cymbium ................. 7

7a. Palpal embolus visible as a prominent loop supported by conductor (1957b, fig. 73); probably cosmopolitan, Florida, Caribbean ……............. S. erigoniformis (O. P.-Cambridge)

7b. Palpus otherwise

8a. Palpus with a transverse, ventral embolus base and a prominent short thread-shaped embolus portion (1957b, fig. 74) ; cosmopolitan; coast states, wide-spread in Mexico and South America S. grossa (C. L. Koch)

8b. Palpus otherwise

9a. Palpal embolus ventral, with a short distal hook as in $1957 \mathrm{~b}$, fig. I8; southern Mexico to southern Brazil

S. moesta (O. P.-Cambridge)

9b. Palpus otherwise

IOa. Palpus with biforked embolus (Fig. 22); northern Colombia

S. marta n. sp.

Iob. Palpus otherwise

II

I Ia. Palpus with spine on base of embolus and complex U-shaped radix (1957b, fig. II; Figs. 44-48); southern Mexico to southern Patagonia …...................... S. ancorata (Holmberg)

I Ib. Palpus otherwise

I2a. Palpus with prominent ventral embolus (Fig. I8); chelicerae tuberculate (Fig. I9); Venezuela, Ecuador, Peru to Chile $S$. andina (Keyserling)

I2b. Palpus and chelicerae otherwise 
13a. Palpal embolus appearing as a tightly coiled structure supported by the conductor (Fig. 30). Minas Gerais, Brazil

S. diamantina n. sp.

I3b. Palpus otherwise

14a. Palpus with a long narrow radix (in ventral view) whose axis is parallel to that of the cymbium (Fig. 27); Bolivia, Chile, Argentina S. sabulosa (Tullgren)

I4b. Palpus otherwise I5

I5a. Palpal embolus small, on distal, ventral side of bulb (1957b, fig. I4) ; Mexico S. quaesita (O. P.-Cambridge)

I5b. Palpus with embolus on ectal side or hidden in ventral view.. I6

I6a. Palpus with prominent ventral radix (1957b, fig. 27); southern California, Texas, Mexico S. transversa (Banks)

r6b. Palpus otherwise (1957b, fig. 30) ; Georgia, Gulf states, West Indies, Mexico to Venezuela

S. quadrimaculata (O. P.-Cambridge)

I 7a. Epigynum with a wrinkled area (Figs. 39, 43) ................ I 8

I 7 b. Epigynum with all parts smooth …............................... 20

I8a. Epigynum with a shield having its anterior margin lobed (1957b, fig. 67) ; ducts coiled (1957b, fig. 66); southern Canada to central Mexico; common in northeastern states

S. americana (Emerton)

I8b. Epigynum without lobed anterior margin; ducts not coiled .. I9

19a. Epigynum as in Figure 39; Chile ………... S. porteri (Simon)

19b. Epigynum as in Figure 43; southern Mexico to southern Patagonia

$S$. ancorata (Holmberg)

20a. Epigynum with a light, transverse, oval, surrounded on sides and behind by a raised area (Fig. 26) ; Bolivia, Chile, Argentina

S. sabulosa (Tullgren)

2ob. Epigynum otherwise $2 \mathrm{I}$

2ra. Epigynum with a median lobe extending from anterior (Figs. I 7, 21) 22

2rb. Epigynum without anterior lobe 27

22a. Posterior margin of epigynum heavily sclerotized and projecting in middle (Fig. 21), northern Colombia S. marta n. sp.

22b. Epigynum otherwise 23

23a. Epigynum with a depression along posterior margin (1957b, figs. 58,72 )

23b. Epigynum otherwise

25

24a. Posterior median depression bordered on each side by a thorn 
(1957b, fig. 58); southern Canada to central Mexico

S. albomaculata (De Geer)

24b. Posterior depression not bordered on sides (1957b, fig. 72); cosmopolitan; Florida, Caribbean

S. erigoniformis (O. P.-Cambridge)

25a. Epigynum with two widely separated depressions (Figs. 34, 35); southern Brazil, Paraguay, Argentina

S. iheringi (Keyserling)

25b. Epigynum otherwise 26

26a. Depression of epigynum bordered all around (Fig. I7) ; Venezuela, Ecuador, Peru to Chile S. andina (Keyserling)

26b. Depression on each side of lobe not bordered behind (1957b, figs. 84, 85) ; cosmopolitan, coast states, widespread in Mexico and South America S. grossa (C. L. Koch)

27a. Epigynum with a narrow, transverse bridge (I957b, fig. 8I); probably introduced and widespread in United States and South America S. triangulosa (Walckenaer)

27b. Epigynum otherwise 28

28a. Epigynum with a median dark spot (1957b, fig. I7) ; southern Mexico to southern Brazil ....... S. moesta (O. P.-Cambridge)

28b. Epigynum otherwise 29

29a. Epigynum with a posterior directed lobe, posterior to the opening (Fig. 32) ; Peru S. chinchipe n. sp.

29b. Epigynum otherwise 30

30a. Epigynum with a slit-like opening on each side (1957b, fig. 20); Mexico S. saltensis Levi

3ob. Epigynum otherwise $3 \mathrm{I}$

31a. Epigynum with shallow longitudinal oval depression (Fig. 29); Minas Gerais, Brazil S. diamantina n. $\mathrm{sp}$.

3I b. Epigynum otherwise 32

32a. Epigynum with a deep transverse depression (Fig. 24); Peru S. variipes (Keyserling)

32b. Epigynum otherwise 33

33a. Epigynum with two black spots on posterior margin (1957b, fig. 24) ; southern California, Texas, Mexico

S. transversa (Banks)

33b. Epigynum otherwise 34

34a. Epigynum with a pair of shallow depressions each with a black spot (1957b, fig. 29); Georgia, Gulf States, West Indies, Mexico to Venezuela .... S. quadrimaculata (O. P.-Cambridge)

34b. Epigynum as in 1957b, fig. 22; Mexico .. S. autumnalis (Banks) 


\section{Steatoda moesta (O. P.-Cambridge)}

Asagena moesta O. P.-Cambridge, 1896, Biologia Centrali-Americana, Araneidea, 1:209, pl. 25, fig. 4, o. Female type from Guatemala in the British Museum, Natural History.

Steatoda moesta, Levi, 1957, Bull. Mus. Comp. Zool., 117:3, p. 379, figs.15-18, 우, $\hat{o}$.

Distribution. Southern Mexico to southern Brazil.

Additional Records. Venezuela: "Caracas, 'Tovar," I888 (E. Simon, MNHN). Peru. Huánuco: $27 \mathrm{~km} \mathrm{~N}$ of Huánuco, Dec. I954 (E. I. Schlinger, E. S. Ross, CAS). San Martin: Tarapoto (MNHN); Moyobamba (MNHN). Brazil. Rio de Janeiro: Mendes (Eidmann, SMF); Teresópolis (MNHN).

\section{Steatoda erigoniformis (O. P.-Cambridge), new combination}

Theridion erigon forme O. P. - Cambridge, 1872, Proc. Zool. Soc. London, p. 284. Female, male syntypes from Jordan in the Hope Department of Entomology, Oxford, examined.

Asaganella crigoniformis, Schenkel, 1937, Festschrift E. Strand, 3:381, fig. 3 , ô.

Lithyphantes septemmaculatus Keyserling, 1884, Die Spinnen Amerikas, $2(1): 141$, pl. 6, fig. 88 , ․ . Female syntypes from "Denver in Columbia" collected by Marx. (Marx's labels are often wrong and the Denver type locality is undoubtedly an error). NEW SYNONYMY.

Distribution. Cosmopolitan. Florida, Caribbean, Panama, Venezuela in America. Kaston (1948, Bull. Connecticut Geol. Nat. Hist. Surv. no. 70:79) reports a specimen from Connecticut. O. Kraus (in a letter) tells of a specimen from Japan in the Senckenberg Museum. It also has been found in the Near East.

Additional Records. Panama Canal Zone: Gamboa, 7 Jan. 1958, $\sigma^{7}$ (A. M. Chickering). British West Indies: Antigua: St. John, I955 (A. M. Nadler, AMNH). Venezuela. Aragua : Tovar, i 888, o (E. Simon, MNHN). Carabobo: San Estebán, i888, ㅇ ô (E. Simon, MNHN).

\section{Steatoda triangulosa (Walckenaer)}

Aranea triangulosa Walckenaer, 1802, Faune Parisienne, 2:207. Type from Paris, France, lost.

Steatoda triangulosa, Levi, 1957, Bull. Mus. Comp. Zool. 117 (3) : 407, figs. 75, $76,80-82$, 우 $\hat{o}$.

Distribution. Central and southern Europe, southern Russia, Mediterranean, United States from Massachusetts to Oregon, south to southern Texas. The city-dwelling habit suggests that it has been 
introduced in America. It has previously been reported from South America, but only one specimen was seen.

Additional Records. Argentina. Santiago del Estero: Santiago del Estero, I2 June ig6r, ㅇ (J. Abalos).

\section{Steatoda grossa (C. L. Koch)}

Theridion grossum C. L. Koch, 1938, Die Arachniden, 4:112, fig. 321, ㅇ. Female types from Greece.

Steatoda punctilineata Mello-Leitão 1939, Rev. Suisse de Zool., 46:61, figs. 30,31 , 9 . Two female syntypes from Leones, Argentina, in the Naturhistorisches Museum, Basel, examined. NEW SYNONYMY.

Steatoda grossa, Levi, 1957, Bull. Mus. Comp. Zool., $117(3): 404$, figs. 74, 83-85, 우 $\hat{0}$.

Note. Mello-Leitão ( I939) figure $3 \mathrm{I}$ is printed upside down; if it had been turned around the synonymy with the common $S$. grossa would have been recognized earlier. Steatoda grossa females can be confused with females of $S$. andina. Only details of the posterior rim of the epigynum seem to separate females of the two species. The male palpi, however, are very different.

Natural History. The species has been collected in subtropical rain forests in Oxapampa, and under stones on guano islands.

Distribution. Cosmopolitan; along coast of United States, Mexico, South America.

Additional records. Ecuador. Tungurahua: Ambato, June 1943 (H. E., D. L. Frizzell). Peru. Isl. Don Martín (Guano Isl.) (L. Peña, SMF) ; Piura: Negritos (H. E., D. L. Frizzell). ? Ancash: Chimbote, Feb. I953 (W. Weyrauch). Pasco: Oxapampa, I6oo m, $\mathrm{E}$ of Oroga (W. Weyrauch). Chile. Antofagasta: Taltal (H. Zapfe). Coquimbo: La Serena (H. Zapfe); Los Vilos (H. Zapfe). Aconcagua: San Filipe (L. Peña, ISNB). Santiago: Santiago (H. Zapfe). Linares: Linares (L. Peña, ISNB). Malleco: Angol, I950 (D. S. Bullock). Osorno: Osorno (L. Peña, ISNB).

\section{Steatoda andina (Keyserling), new combination} Figures I6-19

Lithyphantes andinus Keyserling, 1884, Die Spinnen Amerikas, Theridiidae, 2(1): 132, pl. 6, fig. 82, ㅇ ô. Male and female syntypes from Junín, Amable Maria, Lima and San Mateo, Peru in the Polish Academy Sciences, Warsaw. A female specimen determined by Keyserling, in the British Museum, Natural History, examined.

Description. Carapace, sternum reddish brown, legs lighter. Abdomen purplish black with a narrow white line around sides, crossed 
in front by a median narrow white line. Very variable, sometimes with a longitudinal white line or almost black. Venter with a lighter $\mathrm{W}$-shaped mark and lighter spots on sides. Eyes subequal in size, anterior median eyes one diameter apart, one and one-half diameters from laterals. Posterior median eyes about one diameter apart, two diameters from laterals. Chelicera of female with a blunt, fleshy tooth on anterior margin, that of male enlarged as in the genus Enoplognatha, with a large tooth on anterior margin (Fig. 19); there is no tooth, however, on posterior margin. Measurements of specimens from Lima, Peru. Total length of female $8.3 \mathrm{~mm}$. Carapace, $3.7 \mathrm{~mm}$ long, $2.9 \mathrm{~mm}$ wide. First femur, $4.3 \mathrm{~mm}$; patella and tibia, $5.1 \mathrm{~mm}$; metatarsus, $3.7 \mathrm{~mm}$; tarsus, I.6 mm. Second patella and tibia, $4 . \mathrm{I}$ $\mathrm{mm}$; third, $3.3 \mathrm{~mm}$; fourth, $5.0 \mathrm{~mm}$. Total length of male, $8.6 \mathrm{~mm}$. Carapace, $4.2 \mathrm{~mm}$ long, $2.7 \mathrm{~mm}$ wide. First femur, $4.7 \mathrm{~mm}$; patella and tibia, $5.5 \mathrm{~mm}$; metatarsus, $4.3 \mathrm{~mm}$; tarsus, $1.9 \mathrm{~mm}$. Second patella and tibia, $4.3 \mathrm{~mm}$; third, $3.6 \mathrm{~mm}$; fourth, $5.0 \mathrm{~mm}$.

Variation. The epigynum (fig. I7) is variable in proportion. A male from Chile has a shorter embolus than males examined from central Peru.

Diagnosis. The more discrete posterior rim of the depression of the epigynum (Fig. I7) separates this species from $S$. grossa (1957b, figs. 84,85 ) with which it may be confused. The palpus (Fig. I8) is very different from that of $S$. grossa.

Natural History. Collected in stony grassland near Lake Junín, shrubs in dry valley in Cajamarca and in Eucalyptus forest in Ancash.

Records. Venezuela. Aragua: Maracay (SMF). Ecuador. Manabi: Manta (D. L. Frizzell). Guayas: Baños de San Vincente, Santa Elena Peninsula (R. W. Landes); W of Guayaquil (R. W. Landes); Colonche (R. W. Landes). Azuay: $22 \mathrm{~km} \mathrm{E} \mathrm{of} \mathrm{Cuenca}$ (E. I. Schlinger, E. S. Ross). Peru. Piura: El Alto (R. Wells); Río Quíroz (H. E., D. L. Frizzell) ; Negritos (H. S. M.) ; Pariñas Valley (H. E., D. L. Frizzell) ; Quebrada Mogollon (H. E., D. L. Frizzell) ; Máncora (H. E., D. L. Frizzell). Cajamarca: Cajamarca, $2700 \mathrm{~m}$ (W. Weyrauch) between Lives and Mirador, near San Miguel de Pallaques, I050 $\mathrm{m}$ (H. W. Koepcke, SMF). Libertad: Otusco (E. I. Schlinger, E. S. Ross, AMNH). San Martín: Hara, $32 \mathrm{~km}$ SE of Moyobamba (F. Woytkowski, AMNH). Ancash: Puna near Huarás, $4300 \mathrm{~m}$ (W. Weyrauch, AMNH); Huarás (H. W. Koepcke, SMF). Huánuco: $27 \mathrm{~km} \mathrm{~S}$ of San Rafael (E. I. Schlinger, E. S. Ross) ; Tingo María, $670 \mathrm{~m}$ (W. Weyrauch, AMNH). Lima: $3 \mathrm{~km} \mathrm{E}$ of San Mateo (E. I. 
Schlinger, E. S. Ross). San Mateo, $3000 \mathrm{~m}$ (W. Weyrauch, AMNH). Lima (H. E., D. L. Frizzell); Canta, 2800 m (W. Weyrauch); Matucana, 2300-2500 m (H. W. Koepcke, SMF); Atocongo Lomas, rocky hills (H. W. Koepcke, SMF). Junin: Tarma, 3I00 m (W. Weyrauch, AMNH). Laguna Algacocha, near Laguna Junín, $4300 \mathrm{~m}$ (H. W. Koepcke, SMF). Laguna Junín, $4140 \mathrm{~m}$ (H. W. Koepcke, SMF). Cuzco: Cuzco, $4000 \mathrm{~m}$ (J. C. Pallister, AMNH). Arequipa: Atiquipa, Chala, $200 \mathrm{~m}$ (W. Weyrauch). Puno: Io km S of Oroya (E .S. Ross, E. M. Michelbacher, CAS). Chile. Tarapacá: Putre, (Avilés); Oasis de Miñimiñe, (Avilés).

\section{Steatoda marta new species}

Figures 20-22

Type. Male from Sierra Nevada de Santa Marta, Magdalena, Colombia (Dulm), in the Muséum National d'Histoire Naturelle, Paris (no. 18389). The specific name is a noun in apposition, after the type locality.

Description. Carapace, sternum, legs rich dark red-brown. Abdomen purplish black with a median dorsal longitudinal white line and a white line around the anterior edge of the abdomen. Anterior median eyes slightly smaller than others, their diameter apart, one and one-half to two diameters from laterals. Posterior median eyes one and one-quarter diameters apart, two diameters from laterals. Laterals separated by about their radius. Chelicerae of male corniculate, with a blunt tooth. Female chelicerae smooth with a short tooth on anterior margin. First and fourth legs subequal in length. Abdomen of male with four sclerotized round spots on dorsum. Total length of male $7.2 \mathrm{~mm}$. Carapace $3.0 \mathrm{~mm}$ long, $2.3 \mathrm{~mm}$ wide. First patella and tibia, $3.5 \mathrm{~mm}$; second, $2.9 \mathrm{~mm}$; third, $2.5 \mathrm{~mm}$. Fourth femur, $3.0 \mathrm{~mm}$; patella and tibia, $3.7 \mathrm{~mm}$; metatarsus, $2.5 \mathrm{~mm}$; tarsus, I. $\mathrm{mm}$. Total length of female $8.0 \mathrm{~mm}$. Carapace $3.2 \mathrm{~mm}$ long, $2.5 \mathrm{~mm}$ wide. First patella and tibia, $3.5 \mathrm{~mm}$; second, $2.9 \mathrm{~mm}$; third, $2.6 \mathrm{~mm}$. Fourth femur, $3.3 \mathrm{~mm}$; patella and tibia, $4.0 \mathrm{~mm}$; metatarsus, $2.5 \mathrm{~mm}$; tarsus, I.I $\mathrm{mm}$.

Diagnosis. This species is very close to Steatoda andina (Keyserling) but differs in having the embolus shorter with a spur, in having a smaller conductor, and having a median apophysis of different shape (Fig. 22). The female epigynum differs in having a scape in a shallow depression. The depression is not bordered. The posterior edge of the 

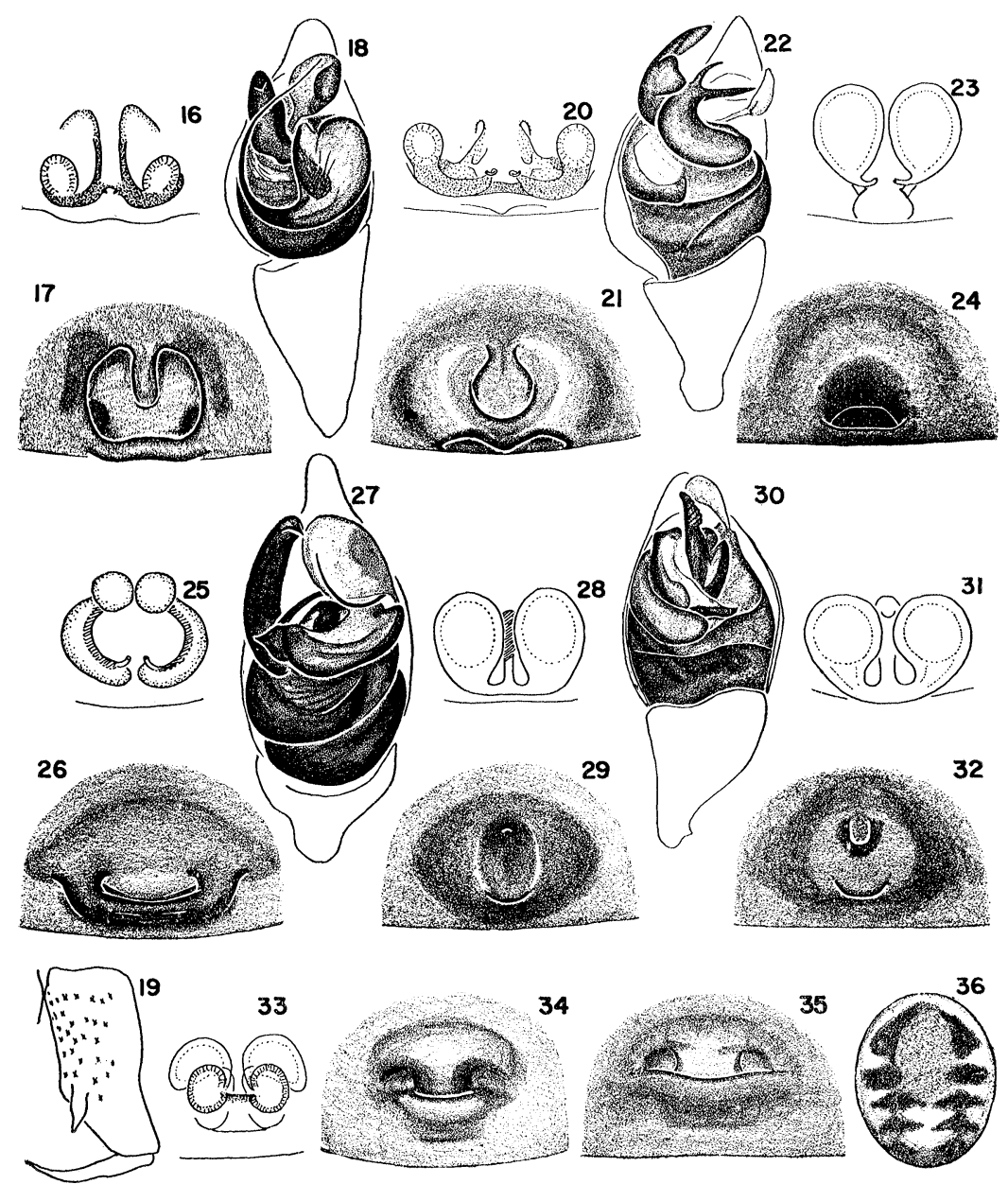

Figs. 16-19. Steatoda andina (Keyserling). 16. Female genitalia, dorsal view. 17. Epigynum. 18. Left palpus. 19. Left male chelicera, anterior view. Figs. 20-22. S. marta new species. 20. Female genitalia, dorsal view. 21. Epigynum. 22. Palpus.

Figs. 23-24. S. variipes (Keyserling). 23. Female genitalia, dorsal view. 24. Epigynum.

Figs. 25-27. S. sabulosa (Tullgren). 25. Female genitalia, dorsal view. 26. Epigynum. 27. Palpus.

Figs. 28-30. S. diamantina new species. 28. Female genitalia, dorsal view. 29. Epigynum. 30. Palpus.

Figs. 31-32. S. chinchipe new species. 31. Female genitalia, dorsal view. 32. Epigynum.

Figs. 33-36. S. iheringi (Keyserling). 33. Female genitalia, dorsal view. 34, 35. Epigynum. 34. Type. 35. (Paraguay). 36. Female abdomen, dorsal view (Paraguay). 
epigynum is heavily sclerotized (Fig. 2r). The scape is sometimes subcircular, sometimes not constricted anteriorly (its sides being nearly parallel), and is sometimes constricted at its posterior point and widens again; its shape seems to be variable in different specimens collected together.

Records. Several o paratypes from type collection.

\section{Steatoda sabulosa (Tullgren), new combination}

Figures 25-27

Lithyphantes sabulosus Tullgren, 1901, Svenska Exped. Magellansländern $2(10): 193$, pl. 1, fig. 3, $\hat{\delta}$. Male type from Santa Cruz, in South Argentina, in the Naturhistoriska Riksmuseum, Stockholm, examined.

Steatoda albiornata Mello-Leitão, 1940, Rev. Mus. La Plata, n.s., $2: 36$, fig. 34, + . Female type from Valcheta, Río Negro, Argentina in the Museo de la Plata, examined. NEW SYNONYMY.

Description. (Specimens from Magellanes, Chile). Carapace, sternum, legs yellow-brown to reddish brown. Abdomen purplish black; dorsum of female abdomen with pigment missing in some areas; white line around anterior of abdomen on dorsum and median, dorsal, longitudinal white line which may be broken. Anterior median eyes slightly smaller than others, two-thirds diameter apart, two-thirds diameter from laterals. Posterior median eyes a little less than a diameter apart, one diameter from laterals. The posterior median eyes of the male are slightly farther from laterals. Male chelicerae not large, with one large tooth, fang widened and short. Total length of female $10.5 \mathrm{~mm}$. Carapace $3.2 \mathrm{~mm}$ long, $2.9 \mathrm{~mm}$ wide. First patella and tibia $4.0 \mathrm{~mm}$; second $2.9 \mathrm{~mm}$; third $2.7 \mathrm{~mm}$. Fourth femur $3.5 \mathrm{~mm}$; patella and tibia $4.2 \mathrm{~mm}$; metatarsus $3.6 \mathrm{~mm}$; tarsus $2.3 \mathrm{~mm}$. Total length of male $8.0 \mathrm{~mm}$. Carapace $3.3 \mathrm{~mm}$ long, 2.5 $\mathrm{mm}$ wide. First patella and tibia $4.0 \mathrm{~mm}$; second $3.6 \mathrm{~mm}$; third 2.9 $\mathrm{mm}$. Fourth femur $3.5 \mathrm{~mm}$; patella and tibia $4.2 \mathrm{~mm}$; metatarsus 3.I $\mathrm{mm}$; tarsus $\mathrm{I} .4 \mathrm{~mm}$.

The internal female genitalia (Fig. 25) are heavily sclerotized. A female from northern Chile has the seminal receptacles slightly wider apart and the ducts forming a $\mathrm{V}$ rather than a circle.

Record. Bolivia. La Paz: La Paz, (MNHN); $48 \mathrm{~km} \mathrm{~N}$ of Potosí, 22 Feb. I95 I (E. S. Ross, A. E. Michelbacher, CAS). Chile. Antofagasta: Tumbre, $3600 \mathrm{~m}$, Cord. Antofagasta, Dec. 1955 (L. Peña, ISNB). Santiago: Santiago (SMF); Los Valdes, $2000 \mathrm{~m}$, Cordilleras near Santiago (G. Mann, AMNH). Magallanes: Laguna Amarga, Natales, Dec. 1960, ㅇ ô (L. Peña). 
Steatoda iheringi (Keyserling), new combination

Figures 33-36

Lithyphantes iheringi Keyserling, 1886, Die Spinnen Amerikas, Theridiidae, $2(2): 240$, pl. 20, fig. 295 , 9 . Female type from Rio Grande do Sul, Brazil, in the British Museum, Natural History, examined.

Lithyphantes cancellatus Mello-Leitão, 1944, Rev. Mus. La Plata, n.s.. $3: 325$, fig. 8, 9 . Female type from José C. Paz, Provincia de Buenos Aires, Argentina in the Museo de la Plata, examined. NEW SYNONYMY.

Description. Specimen from Paraguay. Carapace yellow-brown, cephalic area brown, sternum red-brown, legs yellow, ends of tibiae darker. Abdomen with two series of dark spots on dorsum; sides and area between posterior spots with some white pigment. Venter darker with a small white mark just posterior to the epigynum. Anterior median eyes slightly smaller than others, one diameter apart, one diameter from laterals. Posterior median eyes three-quarters diameters apart, one and one-half diameters from laterals. Chelicerae with one tooth on the anterior margin. Legs quite thick, first equal in length to fourth. Epigynum (Figs. 34, 35) with a transverse fold. Internal genitalia difficult to study; the anterior ducts are very transparent and in the single specimen available, could not be seen completely. Total length of female type $2.9 \mathrm{~mm}$. Carapace $\mathrm{I} .30 \mathrm{~mm}$ long, $1.08 \mathrm{~mm}$ wide. First femur, I.04 mm; patella and tibia, $\mathrm{r} .43$ $\mathrm{mm}$; metatarsus, $0.84 \mathrm{~mm}$; tarsus, $0.52 \mathrm{~mm}$. Second patella and tibia, I.IO $\mathrm{mm}$; third, $0.95 \mathrm{~mm}$; fourth, $1.50 \mathrm{~mm}$.

The palpus illustrated by Figure 48 may belong to the male of this species. It was collected with females of $S$. ancorata in Rio Grande do Sul and belongs to the Keyserling collection in the British Museum.

Records. Paraguay: Taquararapa, Alto Parana, I908, o (AM $\mathrm{NH})$. Argentina. Buenos Aires, ㅇ( (Latarte, MNHN).

\section{Steatoda diamantina new species}

Figures 28-30

Type. Female from Mina Serinha, Diamantina, Minas Gerais, Brazil, December 1944 (Mrs. E. Cohn), in the American Museum of Natural History. The specific name is a noun in apposition, named after the type locality.

Description. Carapace, sternum, legs red-brown. Abdomen black except for one or two thin jagged white lines around sides and anterior. A median, longitudinal, dorsal white line varies in thickness and has several short pairs of lateral branches. Eyes subequal in size, in female. Anterior median eyes two-thirds diameter apart. 
Posterior median eyes their radius apart and one diameter from laterals. Anterior median eyes of male slightly larger than others, one-third diameter apart, one-quarter diameter from laterals. Posterior median eyes one-third diameter apart, one diameter from laterals. Chelicerae of male with one tooth on anterior margin. First femora of male swollen and corniculate on venter. Total length of male 6.6 mm. Carapace $3.3 \mathrm{~mm}$ long, $2.4 \mathrm{~mm}$ wide. First femur $4.3 \mathrm{~mm}$; patella and tibia $3.9 \mathrm{~mm}$; metatarsus $2.9 \mathrm{~mm}$; tarsus $\mathrm{I} .5 \mathrm{~mm}$. Second patella and tibia $3.2 \mathrm{~mm}$; third $2.7 \mathrm{~mm}$; fourth $3.9 \mathrm{~mm}$. Total length of female 6.I mm. Carapace $2.9 \mathrm{~mm}$ long, 2.I $\mathrm{mm}$ wide. First femur $3.5 \mathrm{~mm}$; patella and tibia $3.9 \mathrm{~mm}$; metatarsus $3.0 \mathrm{~mm}$; tarsus $\mathrm{I} .4 \mathrm{~mm}$. Second patella and tibia $2.9 \mathrm{~mm}$; third $2.3 \mathrm{~mm}$; fourth $3.5 \mathrm{~mm}$.

Diagnosis. This species is separated from other Steatoda by the epigynum (Fig. 29), which has a shallow, oval to round depression, the anterior end of which is dark and contains the opening. The male can be separated by the structure of the palpus (Fig. 30).

Records. Brazil. Santa Catarina: Nova Teutonia, lat $27^{\circ}$ I I' S, long $52^{\circ} 23^{\prime} \mathrm{W}$, o , $0^{\star}$ (F. Plaumann, SMF).

\section{Steatoda chinchipe new species}

Figures 31, 32

Type. Female from Río Chinchipe, San Ignacio, $800 \mathrm{~m}$ elev., Cajamarca, Peru, July 1948 (W. Weyrauch) in the Museum of Comparative Zoology. The specific name is a noun in apposition, after the type locality.

Description. Carapace, sternum, legs brown. Abdomen evenly purplish black with a wavy line around sides and anterior on dorsum; center of dorsum with a fine longitudinal white line having two crosslines. Anterior median eyes smaller than other eyes. Anterior median eyes three-quarters their diameter apart, one diameter from laterals. Posterior median eyes their radius apart, slightly more than one diameter from laterals. Lateral eyes slightly separated. Total length $7.5 \mathrm{~mm}$. Carapace $3.2 \mathrm{~mm}$ long, $2.5 \mathrm{~mm}$ wide. First femur $3.5 \mathrm{~mm}$; patella and tibia $4.2 \mathrm{~mm}$; metatarsus $2.7 \mathrm{~mm}$; tarsus $1.3 \mathrm{~mm}$. Second patella and tibia $2.9 \mathrm{~mm}$; third $2.2 \mathrm{~mm}$; fourth $3.7 \mathrm{~mm}$.

Diagnosis. The epigynum differs from that of other Steatoda. It has a raised circular area containing an anterior opening with a lip on three sides (Fig. 32). The internal genitalia (Fig. 3I) are heavily sclerotized.

Records. Ecuador. Tungurahua: Baños, 7 May I942 (H. E. 
Frizzell) ; $32 \mathrm{~km} \mathrm{SE}$ of Ambato, 8 Feb. 1955 (E. I. Schlinger and E. S. Ross, CAS) ; Río Pastaza between Baños and Mapoto, Aug. I938 (W. C. Macintyre).

$$
\begin{gathered}
\text { Steatoda variipes (Keyserling), new combination } \\
\text { Figures 23, } 24
\end{gathered}
$$

Theridium variipes Keyserling, 1884, Die Spinnen Amerikas, Theridiidae, 2(1): 93, pl. 4, fig. 61, ㅇ. Female lectotypes here designated from Amable María [Junín], Peru in the Polish Academy of Science, Warsaw, examined.

Description. Carapace rich brown, sternum yellow-brown with darker margin and darker spot in middle. Legs yellow-brown with darker bands as wide as lighter arcas. Abdomen probably mottled black. Eyes about subequal in size, anterior median eyes one diameter apart, one-quarter diameter from laterals; posterior median eyes one diameter apart, one-third diameter from laterals. Muscle impressions on abdomen and bases of setae slightly sclerotized. Colulus relatively small with two setae. Total length of female lectotype $5.0 \mathrm{~mm}$; carapace $1.0 \mathrm{~mm}$ long, 1.9 mm wide. First femur $2.7 \mathrm{~mm}$; patella and tibia $2.9 \mathrm{~mm}$; metatarsus I. $6 \mathrm{~mm}$; tarsus $0.9 \mathrm{~mm}$. Second patella and tibia $2.3 \mathrm{~mm}$; third I.6 mm; fourth $2.4 \mathrm{~mm}$.

Record: One 9 paratype with type.

\section{Steatoda porteri (Simon), new combination Figures 37-39}

Lithyphantes porteri Simon, 1900, Rev. Chileana, 4:50. Female type from Chañarcillo, [Prov. Atacama], Chile, in the Muséum National d'Histoire Naturelle, Paris, examined.

Description. Carapace, sternum, legs yellow-brown; fourth leg darker than others. Abdomen purplish black with dorsal white marks (Fig. 37) and a small white spot posterior to genital groove on venter. Anterior median eyes slightly smaller than others, one and one-half diameters apart, one diameter from laterals. Posterior median eyes one diameter apart, slightly more than one diameter from laterals. One broad tooth on anterior margin of chelicerae. Fourth leg slightly longer than first. Epigynum (Fig. 39) with a wrinkled knob pointing posterior. Total length $4.7 \mathrm{~mm}$. Carapace, I. $8 \mathrm{~mm}$ long, I.4 mm wide. First patella and tibia, $2.1 \mathrm{~mm}$; second, $1.7 \mathrm{~mm}$; third, $1.4 \mathrm{~mm}$. Fourth femur $2.0 \mathrm{~mm}$; patella and tibia, $2.4 \mathrm{~mm}$; metatarsus, I.6 $\mathrm{mm}$; tarsus, $0.9 \mathrm{~mm}$.

Record. Chile. Coquimbo: El Tofo, Sept. 1957 (H. Zapfe). 

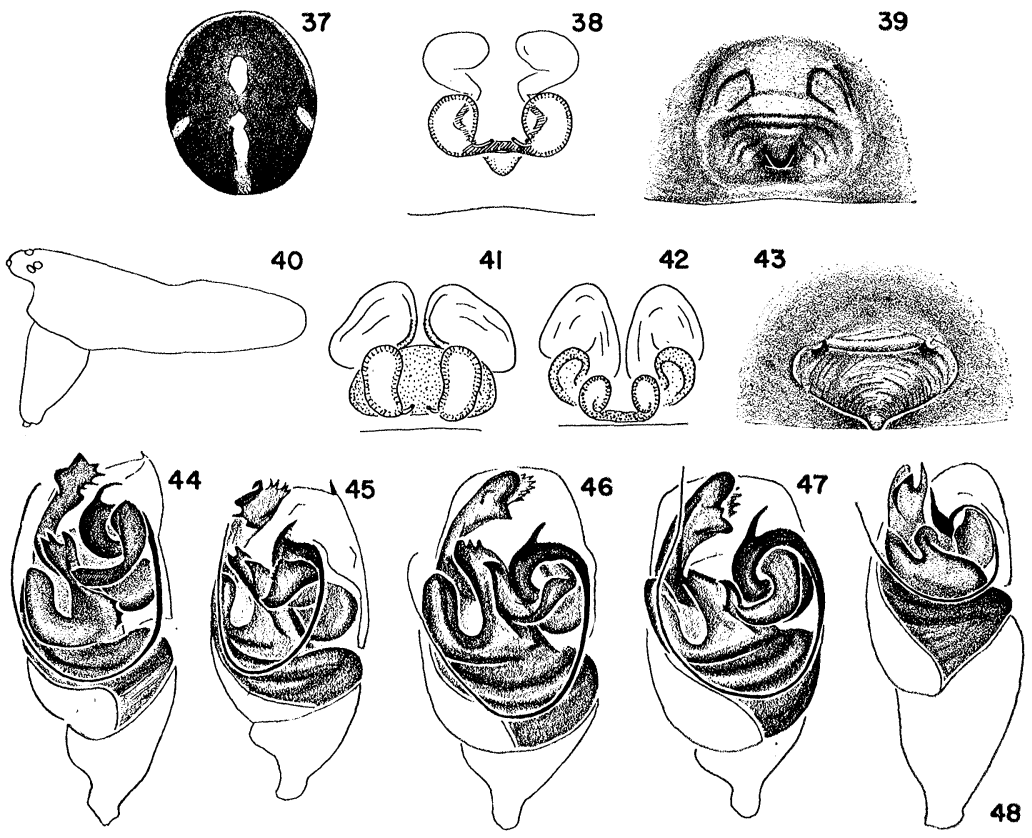

Figs. 37-39. Steatoda porteri (Simon). 37. Female abdomen, dorsal view. 38. Female genitalia, dorsal view. 39. Epigynum.

Figs. 40-47. S. ancorata (Holmberg). Fig. 40. Male carapace and chelicerae. Figs. 41, 42. Female genitalia, dorsal view. 43. Epigynum. 44-47. Palpus. 44. (northern part of range). 45. (southern Peru). 46. (Bolivia). 47. (southern Chile).

Fig. 48. S. ? iheringi (Keyserling), palpus.

\section{Steatoda ancorata (Holmberg), new combination \\ Figures $40-47$}

Theridium ancoratum Holmberg, 1876, An. Agr. Rep. Argentina, 4:72, fig. 16. Type from Argentina, lost.

?Lithyphantes vittatus Keyserling, 1884, Die Spinnen Amerikas, Theridiidae, $2(1): 134$, pl. 6, fig. 83. Juv. type from Minas Gerais, Brazil, in the Hope Department of Entomology, Oxford, examined. NEW SYNONYMY.

Lithyphantes nigrofemoratus Keyserling, 1884, op. cit. 2(1):139, pl. 6, fig. 87, 9 . Female type from Monte Rico, [Ayacucho], Peru, in the Polish Academy of Sciences, Warsaw, examined. NEW SYNONYMY.

Asagena alticeps Keyserling, 1886, op. cit. 2(2):4, fig. 136, ô. Male type from N. Granada [Panama, Colombia, Venezuela] in the British Museum, Natural History. NEW SYNONYMY.

Lithyphantes laetus O. P.-Cambridge, 1896, Biologia Centrali-Americana, Araneidea, 1:181, pl. 22, fig. 12, ô. Male type from Costa Rica, in the British Museum, Natural History. NEW SYNONYMY. 
Asagena patagonica Tullgren, 1901, Svenska Exped. Magellansländern 2: 194, pl. 15, fig. 4, + . Female type from Ultima Esperanza and Puerto Gallegus, Patagonia [? Magellanes, Chile] in the Naturhistoriska Riksmuseum, Stockholm, examined. NEW SYNONYMY.

Asagena melanomela Mello-Leitão, 1944, Rev. Mus. La Plata, n.s., 3:325, fig. 5, $\hat{0}$. Male type from Pergamino, [Buenos Aires], Argentina in the Museo de la Plata, examined. NEW SYNONYMY.

Steatoda nigrofemorata, Levi, 1957, Bull. Mus. Comp. Zool., 117(3):377, figs. 11-13, o $\hat{o}$.

Note. This species is the most common Steatoda in Argentina, the type locality of $T$. ancoratum. Specimens of this species from Argentina determined by Mello-Leitão and by Birabén were named Lithyphantes ancoratum. The synonymy of $L$. vittatus Keyserling remains uncertain, however, as the type is a juvenile and no specimens of $S$. ancorata have been examined from Minas Gerais, the type locality.

The palpi are variable in structure, (Figs. 44-47). Since the palpal sclerites are unusually complex, any slight change in position changes the appearance of the palpus.

Natural History. Specimens have been found "near rockpile in weathered shale" and "under flat rock" in Bolivia. In Mendoza, Argentina it has been found in chaparral area.

Distribution. Southern Mexico to southern Patagonia.

Additional records: Venezuela. Dist Federal: Caracas (E. Simon, MNHN). Aragua: Tovar (E. Simon, MNHN). Colombia. Valle: IO $\mathrm{km} \mathrm{W}$ of Cali (E. I. Schlinger, E. S. Ross, CAS). Peru. Huánuco: Monzón Valley, Tingo María (E. I. Schlinger, E. S. Ross, CAS) ; Huánuco (E. I. Schlinger, E. S. Ross, CAS). A yacucho: Ayacucho (W. Weyrauch). Cuzco: Cuzco, $3800 \mathrm{~m}$ (W. Weyrauch) ; Huadquiña, I6oo m (W. Weyrauch). Puno: $95 \mathrm{~km} \mathrm{~N}$ of Puno (E. S. Ross, A. E. Michelbacher, CAS) ; Puno (W. Weyrauch) ; near Juliaca, $3900 \mathrm{~m}$ (H. W. Koepcke, SMF) ; Mazo Cruz, $3800 \mathrm{~m}$ (L. Peña, ISNB) ; Camacani (L. Peña, ISNB). Bolivia. Chaco (MNHN). La Paz: Timari, Nevada de Chicani (MNHN); La $\mathrm{Paz} 4400 \mathrm{~m}$ (R. Walsh, MNHN); $65 \mathrm{~km} \mathrm{NE}$ of La Paz (R. Walsh); Altiplano near Huayna Potosí Mtn., 5 Ioo m (R. Walsh). Chiquisaca: $26 \mathrm{~km}$ N of Camargo (E. S. Ross, A. E. Michelbacher, CAS). Potosí: $45 \mathrm{~km} \mathrm{~N}$ of Potosí, $4300 \mathrm{~m}$ (E. S. Ross, A. E. Michelbacher, CAS). Brazil. Paraná: Bela Vista (MNHN). Rio Grande do Sul. (BMNH). Paraguay. Asunción (MNHN). Caazapá: Pastoreo (D. Wees). Argentina. Jujuy: $8 \mathrm{~km} \mathrm{~N}$ of Humacuaca, $2900 \mathrm{~m}$ (E. S. Ross, A. E. Michelbacher, CAS). Salta: Salta (Reimoser); Cafayate (M. Birabén). Chaco: Resistencia 
(MNHN). Córdoba: Alta Gracia (Bruch). Mendoza: $8 \mathrm{~km} \mathrm{SSW}$ Estación Cachenta, Dept. Luján, I 500 m (B. Patterson). Buenos Aires: Necochea (M. Birabén); "Bahia" (MNHN). Chile. Antofagasta: Tumbre, $3600-3700 \mathrm{~m}$, Cord. Antofagasta (L. Peña, ISNB). Magallanes: Cerro Castillo, Natales (L. Peña).

\section{REFERENCES}

Gertsch, W. J.

1960. The fulva group of the spider genus Steatoda. Amer. Mus. Novitates, no. 1982, p. 1-48.

LEVI, H. W.

1957a. The spider genera Enoplognatha, Theridion and Paidisca in America North of Mexico. Bull. Amer. Mus. Nat. Hist., 112(1): 1-123.

1957b. The spider genera Crustulina and Steatoda in North America, Central America and the West Indies. Bull. Mus. Comp. Zool. $117(3): 367-424$.

"1959"(1960). Problems in the spider genus Steatoda. Systematic Zool. $8: 107-116$.

The American spiders of the genus Anclosimus. Trans. Amer. Micros. Soc. in press.

LEVI, H. W. and L. R. LeVI

1962. The genera of the family Theridiidae. Bull. Mus. Comp. Zool. 127 (1) :1-71. 

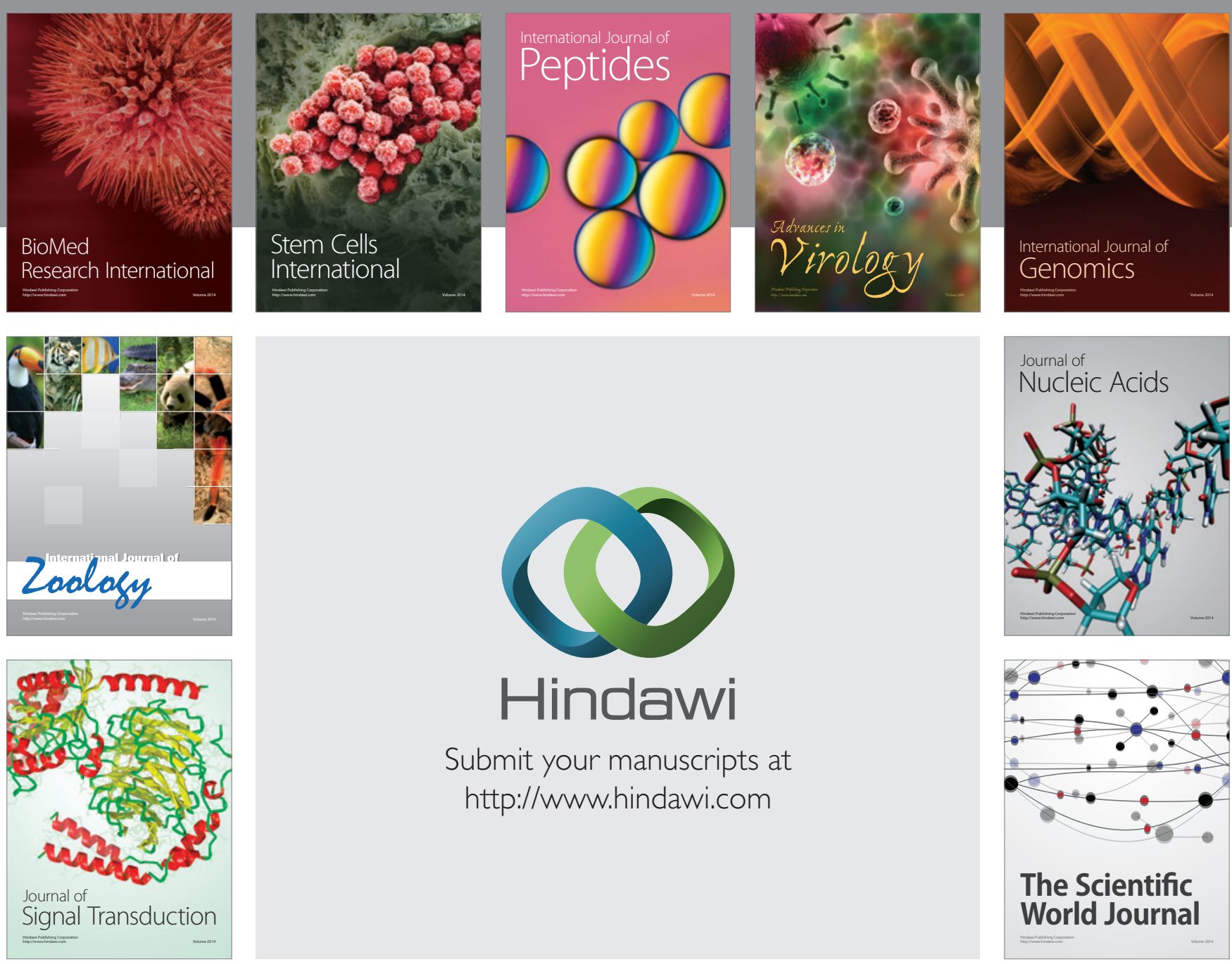

Submit your manuscripts at

http://www.hindawi.com
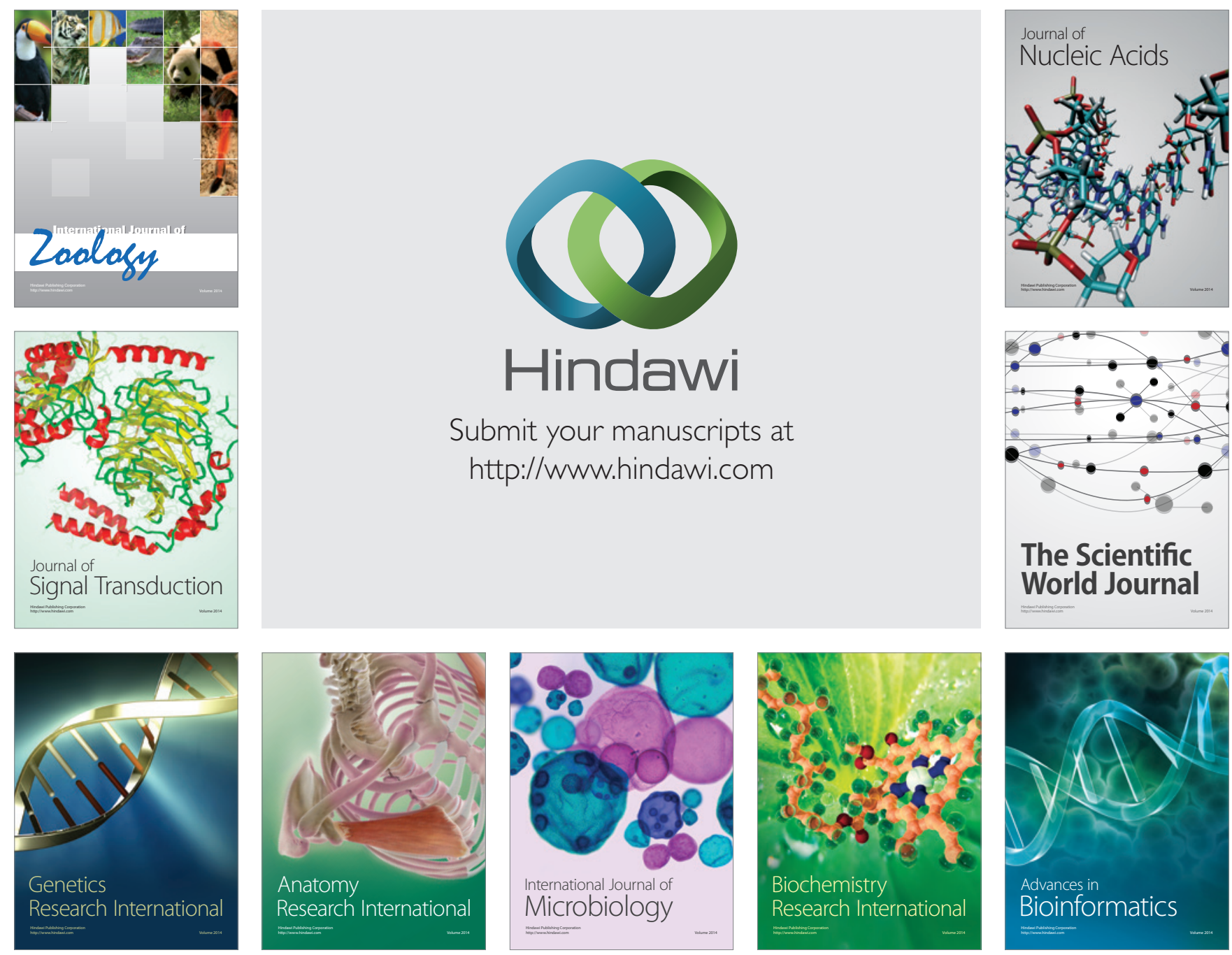

The Scientific World Journal
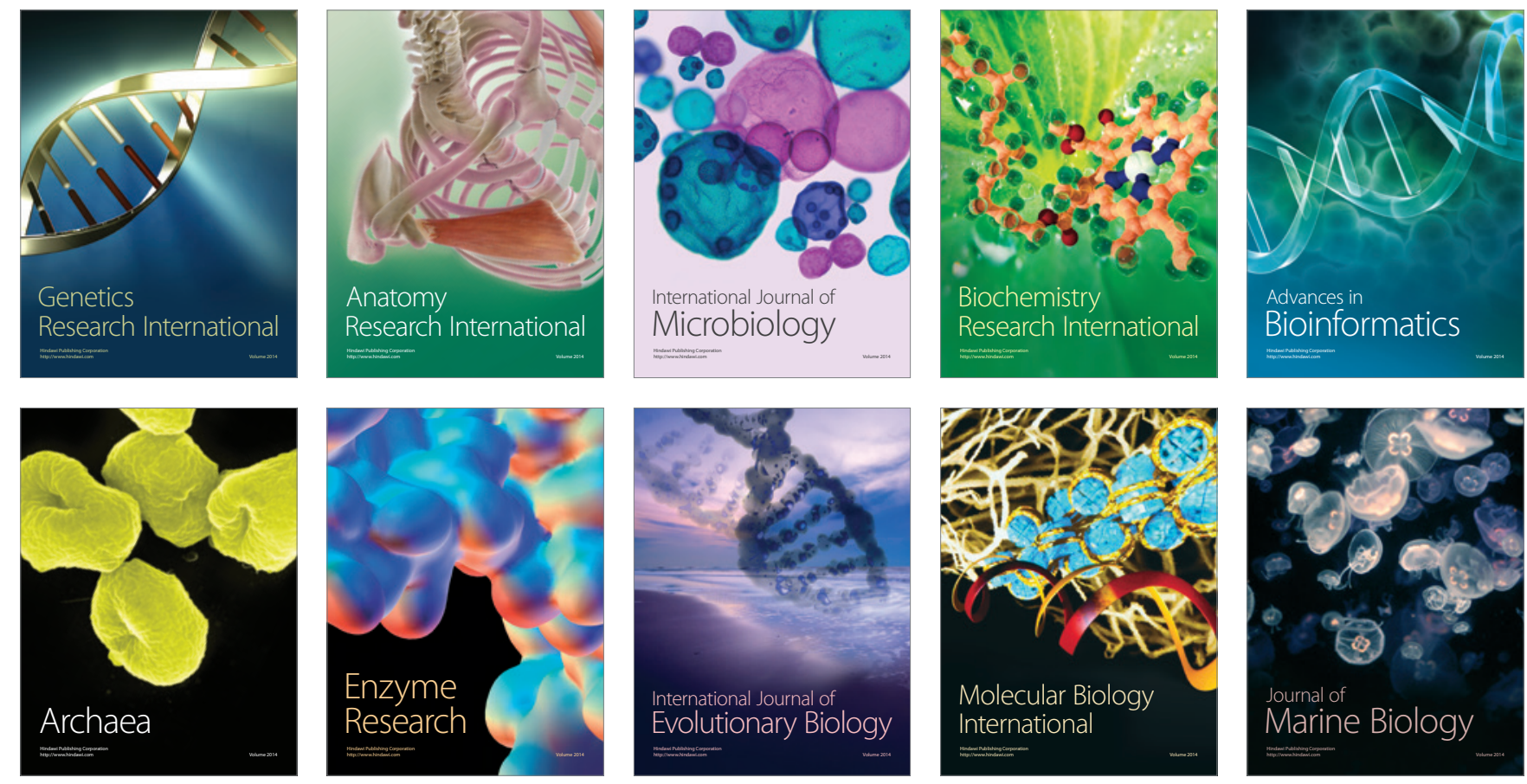